\title{
PENGARUH PEMBERIAN NATA DE COCO TERHADAP KADAR KOLESTEROL LDL DAN HDL PADA WANITA DISLIPIDEMIA
}

\author{
Mohd Ikhsan, Tatik Mulyati* \\ Program Studi Ilmu Gizi Fakultas Kedokteran Universitas Diponegoro \\ Jl.Dr.Sutomo No.14, Semarang, Telp (024) 8453708, Email : gizifk@undip.ac.id
}

\begin{abstract}
Background : Elevated LDL cholesterol (LDL-C) and low HDL (HDL-C) cholesterol related with cardiovasular disease. Cellulose, hemicellulose and lignin are kind of dietary fiber in nata de coco that have hypocholesterolemic effect by lowering LDL-C and increasing HDL-C levels.

Methods : This research was true experimental study with control group pre-test-post-test design. Subjects were 52 women with $\mathrm{LDL}-\mathrm{C}$ level $\geq 100 \mathrm{mg} / \mathrm{dl}$ dan $\mathrm{HDL}-\mathrm{C}$ level $\leq 50 \mathrm{mg} / \mathrm{dl}$, cllasified into 3 groups, control group, group 1 consume $160 \mathrm{~g}$ nata de coco/day (with $4.8 \mathrm{~g}$ of fiber) and group 2 consume $320 \mathrm{~g}$ nata de coco/day (with $9.6 \mathrm{~g}$ of fiber). Nata de coco was consumed during 14 days. phosphotungstic precipilation method was used to analyze HDL-C level and Friedewald equation was used to measure LDL-C. Blood was collected after fasting for 10 hours. Paired-samples t-test, ANOVA and Kruskal-Wallis was used for the statistical test.

Results : Consumption of nata de coco $160 \mathrm{~g} /$ day and $320 \mathrm{~g} /$ day can lower LDL-C $4.47 \%$ (p=0.091) and 6.25\% $(p=0.044)$ and raise HDL $12.1 \%(p=0.001)$ and $3.6 \%(p=0.361)$ respectively. There was significant effect of HDL-C to both groups, but not for $L D L-C$. In control group, there was an increase of $L D L-C$ level $2.54 \%(p=0.005)$ and reduce $H D L-C$ level 0,56 $(p=0.570)$.

Conclusion : Consumption of nata de coco $320 \mathrm{~g} /$ day can lower LDL-C significantly, but for HDL-C, it can raise at dose $160 \mathrm{~g} /$ day significantly.
\end{abstract}

Keywords : nata de coco; LDL cholesterol; HDL cholesterol; women; dislipidemia

\begin{abstract}
ABSTRAK
Latar Belakang : Kadar kolesterol LDL yang tinggi dan HDL yang rendah berkaitan dengan penyebab utama terjadinya penyakit jantung dan pembuluh darah. Serat diketahui dapat menurunkan kadar kolesterol LDL serta meningkatkan kolesterol HDL. Nata de coco mengandung selulosa, hemiselulosa dan lignin yang memiliki efek hipokolesterolemia dalam darah.

Metode : Jenis penelitian adalah true experimental dengan rancangan control group pre-test-post-test. Sebanyak 52 wanita dengan kadar kolesterol $L D L \geq 100 \mathrm{mg} / \mathrm{dl}$ dan $H D L \leq 50 \mathrm{mg} /$ dl menjadi subyek dalam penelitian ini. Subyek dibagi menjadi 3 kelompok, yaitu kelompok kontrol, perlakuan 1 mendapat $160 \mathrm{~g}$ nata de coco/hari (serat $4.8 \mathrm{~g}$ ) dan perlakuan 2 mendapat $320 \mathrm{~g}$ nata de coco/hari (serat $9.6 \mathrm{~g}$ ). Intervensi dilakukan selama 14 hari. Metode phosphotungstic precipilation digunakan untuk menganalisis kadar HDL sementara kadar LDL dianalisis mengunakan rumus Friedewald. Darah diambil setelah subyek berpuasa selama 10 jam. Analisis statistik yang digunakan antara lain paired-samples $t$ test, ANOVA dan Kruskal-Wallis.

Hasil : Konsumsi nata de coco sebanyak 160 g/hari dan 320 g/hari berturut-turut menurunkan kadar kolesterol LDL sebanyak $4.47 \%(p=0.091)$ dan $6.25 \%(p=0.044)$ serta meningkatkan kadar kolesterol HDL sebanyak $12.1 \%$ $(p=0.001)$ dan $3.6 \%(p=0.361)$. Tidak terdapat perbedaan pengaruh pemberian nata de coco terhadap perubahan kadar kolesterol LDL antar kedua kelompok $(p=0.863)$, namun terdapat pengaruh yang bermakna terhadap kolesterol HDL antar kedua kelompok $(p=0.043)$. Sedangkan pada kelompok kontrol terjadi peningkatan kadar kolesterol LDL sebebesar $2.54 \%$ ( $p=0.005)$ dan penurunan kadar kolesterol HDL sebesar 0,56\% ( $p=0.570)$.

Kesimpulan : Konsumsi nata de coco sebanyak 320 g/hari berpengaruh terhadap penurunan kadar kolesterol LDL secara bermakna sedangkan pemberian nata de coco sebanyak 160 g/hari berpengaruh terhadap peningkatan kolesterol HDL secara bermakna.
\end{abstract}

Kata kunci : nata de coco; kolesterol LDL; kolesterol HDL; wanita; dislipidemia

\section{PENDAHULUAN}

Dislipidemia

metabolisme lipid yang ditandai dengan peningkatan maupun penurunan fraksi lipid dalam plasma. Kadar serum kolesterol Low-density lipoprotein (LDL) yang tinggi dan kolesterol Highdesity Lipoprotein (HDL) yang rendah erat hubungannya dengan penyebab utama terjadinya penyakit jantung dan pembuluh darah. ${ }^{1,4}$ Hal ini berkaitan dengan pembentukan plak pada dinding

\footnotetext{
${ }^{*}$ Penulis Penanggungjawab
} 
pembuluh darah akibat teroksidasinya LDL yang memicu proses aterosklerosis.

Berdasarkan RISKESDAS 2007, prevalensi penyakit jantung di Indonesia adalah $7.2 \%$ dan di Jawa Tengah sebesar $8.4 \%$. Wanita merupakan kelompok yang paling banyak dijumpai menderita masalah ini dengan prevalensi $8.1 \%$ dan laki-laki $6.2 \% .^{2}$ Berdasarkan laporan kematian di Rumah Sakit dan Puskesmas dari Dinas Kesehatan Kota Semarang, selama periode 2011 dilaporkan 653 dari 1074 kematian akibat penyakit tidak menular (60.8\%) disebabkan karena penyakit jantung dan pembuluh darah. $^{3}$

Faktor risiko terjadinya dislipidemia antara lain pola diet sehari-hari, jenis kelamin, umur, genetik, aktifitas fisik, dan obesitas. Pengaturan pola diet merupakan target utama yang digunakan untuk menurunkan risiko penyakit kardiovaskuler adalah dengan mengurangi konsumsi kolesterol, lemak total dan lemak jenuh serta meningkatkan asupan serat. ${ }^{1}$ Serat dapat menurunkan risiko penyakit kardiovaskuler melalui mekanisme pengaturan konsentrasi profil lipid dalam darah, yaitu melalui pengikatan asam empedu di saluran cerna, meningkatkan pengeluaran asam empedu melalui feses, dan menghasilkan senyawa asam lemak rantai pendek sebagai hasil fermentasi serat di kolon yang dapat menurunkan sintesis kolesterol. ${ }^{5,6}$

Penelitian tentang pengaruh pemberian suplemen serat serealia yang dikombinasikan dengan $40 \%$ serat nata de coco pada pasien hiperlipidemia dengan total kandungan serat pangan $2.7 \mathrm{~g} / \mathrm{hari}$, selama $20 \mathrm{minggu}$ secara signifikan dapat menurunkan kadar kolesterol total sebesar $8.8 \%$ (23.2 $\mathrm{mg} / \mathrm{dl})$, dan menurunkan kadar kolesterol LDL sebesar $2.3 \%$ (3.9 mg/dl), serta terjadi peningkatan kadar kolesterol HDL sebesar $7.7 \%(3.9 \mathrm{mg} / \mathrm{dl})$ namun secara statistik tidak bermakna. ${ }^{7}$ Penelitian pada tikus Sprague Dawley hiperkolesterolemi, pemberian nata de coco kering dengan kandungan serat $0.18 \mathrm{~g} ; 0.36 \mathrm{~g} ; 0.54 \mathrm{~g}$ dan $0.72 \mathrm{~g}$ per hari selama 2 minggu, diperoleh hasil penurunan LDL dan peningkatan HDL yang signifikan, dengan penurunan LDL berturut-turut $29.9 \%$; $58.9 \%$; $71.3 \%$; dan $84.9 \%$. Sementara peningkatan kadar kolesterol HDL berturut-turut $4.9 \%$; $35.7 \%$; $46.8 \%$; dan $66.1 \% .^{8}$

Nata de coco merupakan salah satu produk pangan olahan tinggi serat yang dihasilkan dari fermentasi air kelapa oleh bakteri Acetobacter xylinum. Produk ini memiliki kandungan tinggi selulosa, lignin, hemiselulosa, rendah lemak dan energi, serta tidak ada kandungan kolesterol. ${ }^{7}$
Penjualan nata de coco di pasaran umumnya dikemas dalam kondisi basah. Kandungan total serat pangan nata de coco basah adalah 3.122 per 100 g nata de coco. ${ }^{8}$

Sebuah studi cross-sectional pada populasi yang dilakukan di Brazil menunjukkan bahwa $85.3 \%$ responden dari wanita usia diatas 20 tahun tergolong dislipidemia. ${ }^{9} \quad$ Peningkatan usia, obesitas, dan aktivitas fisik yang rendah merupakan faktor risiko terjadinya dislipidemia.

Pengaruh pemberian nata de coco pada hewan coba telah dilakukan dan terdapat penurunkan kolesterol LDL dan peningkatan kolesterol HDL dengan signifikan dan tidak ditemukan efek toksik terhadap hewan coba. Hal inilah yang mendasari dilakukannya penelitian ini, untuk melihat pengaruh pemberian nata de coco terhadap profil lipid pada manusia, dengan mengambil subjek wanita usia subur dan pemilihan lokasi penelitian di lingkungan kerja kantor Sekretariat Daerah Provinsi Jawa Tengah dan kantor Badan Perencanaan Pembangunan Provinsi Jawa Tengah sebagai subjek yang dianggap memiliki aktivitas fisik rendah.

\section{METODE}

Penelitian ini merupakan penelitian true experimental dengan rancangan control group pretest-post-test. Variabel bebas dalam penelitian ini adalah dosis nata de coco, sementara variabel terikat adalah kadar kolesterol LDL dan kadar kolesterol HDL penderita dislipidemia.

Subjek penelitian merupakan karyawati kantor Sekretariat Daerah Provinsi Jawa Tengah dan karyawati kantor Badan Perencanaan Pembangunan Provinsi Jawa Tengah, dengan kriteria inklusi memiliki kadar kolesterol LDL $\geq$ $100 \mathrm{mg} / \mathrm{dl}$, kadar kolesterol HDL $\leq 50 \mathrm{mg} / \mathrm{dl}$, indek masa tubuh (IMT) $\geq 18.5 \mathrm{~kg} / \mathrm{m}^{2}$, berusia minimal 30 tahun, belum menopause, tidak sedang mengkonsumsi obat antihiperlipidemi dan tidak dalam keadaan sakit atau dalam perawatan dokter berkaitan dengan penyakit jantung koroner, diabetes melitus, hipertensi, gagal ginjal dan penyakit kronik lainnya. Sebanyak 54 sampel didapat dengan mengunakan perhitungan sampel minimal uji hipotesis terhadap rerata dua populasi independen.

Penentuan subjek penelitian menggunakan metode consecutive sampling. Sebanyak 89 orang bersedia diambil darahnya untuk proses skrining awal dan diperoleh sebanyak 54 orang yang memenuhi kriteria inklusi untuk menjadi subjek penelitian. Subjek dibagi menjadi 3 kelompok 
dengan metode simple random sampling, yang terdiri atas satu kelompok kontrol dan dua kelompok perlakuan, masing-masing kelompok terdiri atas 18 subjek. Kelompok perlakuan 1 mendapatkan nata de coco sebanyak 160 g dengan kandungan serat $4.8 \mathrm{~g}$ dan kelompok perlakuan 2 mendapatkan nata de coco sebanyak 320 g dengan kandungan serat $9.6 \mathrm{~g}$.

Pemberian nata de coco dilakukan selama 14 hari, sementara pada kelompok kontrol, subjek tidak diberikan perlakuan. Konsumsi makan sehari-hari, baik untuk kelompok kontrol maupun kelompok perlakuan tidak dikontrol dan dibiarkan sebagaimana biasanya. Catatan asupan makan dilakukan sebelum dan selama intervensi. Sementara kepatuhan mengkonsumsi nata de coco dikontrol dengan menggunakan formulir daya terima. Terdapat dua subyek yang drop out pada penelitian ini yaitu pada kelompok perlakuan dua, sehingga total subjek dari penelitian ini sebanyak 52 subjek.

Kandungan serat dalam nata de coco yang digunakan dalam penelitian ini yaitu $3 \%$. Nilai ini hampir mendekati kandungan serat dalam nata de coco yang digunakan dalam penelitian terdahulu, yaitu $3.122 \% .^{8}$ Kandungan gula dalam kemasan nata de coco tidak digunakan selama intervensi

Kadar kolesterol HDL ditentukan dengan metode phosphotungstic precipilation. Kadar kolesterol LDL didapat dari perhitungan kadar total kolesterol - kadar kolesterol HDL - 1/5 kadar trigliserida. Darah diambil oleh petugas laboratorium setelah subyek berpuasa selama \pm 10 jam. Data asupan makan subjek dianalisis menggunakan program nutrisurvey 2005.

Uji normalitas menggunakan uji ShapiroWilk. Karekteristik subyek dianalisis dengan menggunakan analisis deskriptif. Data kadar kolesterol LDL kelompok kontrol, perlakuan 1, perlakuan 2 dan kadar kolesterol HDL kelompok perlakuan 1 berdistribusi normal sehingga untuk uji perbedaan kadar kolesterol LDL dan HDL sebelum dan sesudah intervensi pada kelompok tersebut digunakan uji paired-samples $t$ test. Sedangkan uji statistik non parametric Wilcoxon digunakan untuk uji beda kadar kolesterol HDL sebelum dan sesudah intervensi pada kelompok kontrol dan kelompok perlakuan 2, karena data tidak berdistribusi normal. Sementara perbedaan perubahan kadar kolesterol LDL antar tiga kelompok dianalisis dengan uji Kruskal-Wallis, dan kadar kolesterol HDL antar tiga kelompok dianalisis dengan uji ANOVA.

\section{HASIL PENELITIAN \\ Gambaran Subjek}

Tabel 1 menunjukan sebaran umur dan status gizi berdasarkan Indeks Masa Tubuh (IMT) kelompok kontrol, perlakuan 1 dan perlakuan 2 .

Tabel 1. Karakteristik Subjek

\begin{tabular}{|c|c|c|c|c|c|c|c|}
\hline \multirow{2}{*}{ Jenis Pengukuran } & \multicolumn{2}{|c|}{ Kontrol } & \multicolumn{2}{|c|}{ Perlakuan 1} & \multicolumn{2}{|c|}{ Perlakuan 2} & \multirow[b]{2}{*}{$\mathbf{P}$} \\
\hline & $\mathrm{n}$ & $\%$ & $\mathrm{n}$ & $\%$ & $\mathrm{n}$ & $\%$ & \\
\hline \multicolumn{8}{|l|}{ Kelompok Umur } \\
\hline 30-39 tahun & 1 & $5.6 \%$ & 4 & 22.2 & 2 & $12.5 \%$ & \\
\hline 40-49 tahun & 10 & $55.6 \%$ & 10 & $55.6 \%$ & 8 & $50 \%$ & $0.211^{\mathrm{b}}$ \\
\hline 50-59 tahun & 7 & $38.9 \%$ & 4 & $22.2 \%$ & 6 & $37.5 \%$ & \\
\hline \multicolumn{8}{|l|}{ IMT (Indeks Massa Tubuh) } \\
\hline Normal $\left(18,5-22,9 \mathrm{~kg} / \mathrm{m}^{2}\right)$ & 8 & $44.4 \%$ & 4 & $22.2 \%$ & 2 & $12.5 \%$ & \\
\hline Overweight & 4 & $22.2 \%$ & 5 & $27.8 \%$ & 2 & $12.5 \%$ & $0.010^{\mathrm{a}}$ \\
\hline $\left.\mathrm{kg} / \mathrm{m}^{2}\right)$ & 5 & $27.8 \%$ & 6 & $33.3 \%$ & 7 & $43.8 \%$ & \\
\hline $\begin{array}{l}\text { Obesitas } \\
\left.\mathrm{kg} / \mathrm{m}^{2}\right)\end{array} \quad \mathrm{I} \quad(25-29,9$ & 1 & $5.6 \%$ & 3 & $16.7 \%$ & 5 & $31.2 \%$ & \\
\hline Obesitas II $\left(\geq 30 \mathrm{~kg} / \mathrm{m}^{2}\right)$ & & & & & & & \\
\hline
\end{tabular}

a Uji beda ANOVA

b Uji beda Kruskal-Wallis

subjek sebagian besar berada pada kelompok umur 40-49 tahun (53.8\%), dan secara statistik tidak ada perbedaan umur antar ketiga kelompok ( $>>0.05$ ). Sedangkan Indeks Masa Tubuh sebagian besar tergolong obesitas 1 (34.6\%). Hasil uji beda menunjukkan ada perbedaan status gizi antar ketiga kelompok $(\mathrm{p}<0.05)$.

Kadar kolesterol LDL dan HDL sebelum intervensi 
Uji beda kadar kolesterol LDL dan HDL homogenitas subyek sebelum intervensi. awal antar kelompok dilakukan untuk mengetahui

Tabel 2. kadar Kolesterol LDL dan Kolesterol HDL subjek sebelum intervensi

\begin{tabular}{|c|c|c|c|c|}
\hline Karakteristik & Kontrol & Perlakuan 1 & Perlakuan 2 & $\mathbf{P}$ \\
\hline $\begin{array}{l}\text { Kol. LDL } \\
\text { (mg/dl) }\end{array}$ & $151.29 \pm 23.31$ & $147.91 \pm 34.86$ & $147.56 \pm 31.09$ & $0.921^{\mathrm{a}}$ \\
\hline $\begin{array}{l}\text { Kol. HDL } \\
\text { (mg/dl) }\end{array}$ & $\begin{array}{c}49.05(37.00- \\
50.00)\end{array}$ & $45,56 \pm 3,11$ & $\begin{array}{c}47.50(30.00- \\
50.00)\end{array}$ & $0.090^{\mathrm{b}}$ \\
\hline IMT $\left(\mathrm{kg} / \mathrm{m}^{2}\right)$ & $23.95 \pm 3.45$ & $26.30 \pm 4.02$ & $28.28 \pm 4.24$ & $0.010^{\mathrm{a}}$ \\
\hline
\end{tabular}

a Uji beda ANOVA

b Uji beda Kruskal-Wallis

Tabel 2 menunjukkan tidak ada perbedaan kadar kolesterol LDL dan HDL sebelum intervensi antar ketiga kelompok ( $>0.05)$, namun terdapat perbedaan IMT $(\mathrm{p}<0.05)$.

\section{Asupan makan sebelum intervensi}

Uji beda asupan makan antar kelompok dilakukan untuk mengetahui homogenitas subyek sebelum intervensi.

Tabel 3. Asupan makan sebelum intervensi

\begin{tabular}{lcccc}
\hline \multicolumn{1}{c}{ Zat Gizi } & Kontrol & Perlakuan 1 & Perlakuan 2 & P \\
\hline Energi (kkal) & $1467.80 \pm 231.64$ & $1402.00 \pm 273.12$ & $1473.20 \pm 319.06$ & $0.696^{\mathrm{a}}$ \\
Karbohidrat & $211.08 \pm 36.74$ & $188.61 \pm 32.46$ & $195.23 \pm 42.14$ & $0.187^{\mathrm{a}}$ \\
(g) & $47.57 \pm 12.13$ & $45.53 \pm 10.71$ & $54.27 \pm 17.96$ & $0.170^{\mathrm{a}}$ \\
Protein (g) & $49.72 \pm 15.52$ & $54.44 \pm 23.03$ & $53.73 \pm 22.21$ & $0.943^{\mathrm{a}}$ \\
Lemak $(\mathrm{g})$ & $178.61 \pm 121.65$ & $153.54 \pm 121.55$ & $133.23 \pm 98.10$ & $0.518^{\mathrm{a}}$ \\
Kolesterol & $9.07 \pm 3.21$ & $8.94 \pm 4.04$ & $8.51 \pm 2.12$ & $0.873^{\mathrm{a}}$ \\
(mg) & & & & \\
Serat $(\mathrm{g})$ & & & & \\
\hline
\end{tabular}

a Uji beda ANOVA

Tabel 3 menunjukkan tidak ada perbedaan asupan energi, karbohidrat, protein, lemak, kolesterol dan serat antar kelompok sebelum intervensi ( $\mathrm{p}>0.05)$.

\section{Asupan makan selama intervensi}

Faktor yang juga dapat mempengaruhi kadar kolesterol darah adalah asupan energi, protein, lemak, karbohidrat, kolesterol dan serat. Berdasarkan hasil uji beda, tidak ada perbedaan asupan energi, karbohidrat, protein dan lemak antar ketiga kelompok ( $>>0.05)$, namun terdapat perbedaan asupan kolesterol dan serat setelah intervensi $(\mathrm{p}<0.05)$, seperti yang terlihat pada tabel 4.

Tabel 4. Asupan makan selama intervensi

\begin{tabular}{lcccc}
\hline \multicolumn{1}{c}{ Zat Gizi } & Kontrol & Perlakuan 1 & Perlakuan 2 & P \\
\hline Energi (kkal) & $1470.47 \pm 223.95$ & $1450.96 \pm 221.27$ & $1588.70 \pm 274.49$ & $0.211^{\mathrm{a}}$ \\
Karbohidrat & $213.98 \pm 40.87$ & $204.15 \pm 33.76$ & $238.12 \pm 58.45$ & $0.214^{\mathrm{b}}$ \\
$\mathrm{g}$ ) & $45.79 \pm 9.40$ & $46.29 \pm 10.53$ & $47.63 \pm 14.26$ & $0.891^{\mathrm{a}}$ \\
Protein $(\mathrm{g})$ & $49.11 \pm 8.29$ & $47.89 \pm 15.03$ & $49.96 \pm 11.48$ & $0.789^{\mathrm{b}}$ \\
Lemak $(\mathrm{g})$ & $163.85 \pm 67.12$ & $98.41 \pm 36.79$ & $143.77 \pm 69.97$ & $0.016^{\mathrm{b}}$ \\
Kolesterol & $9.61 \pm 3.49$ & $13.59 \pm 2.49$ & $16.75 \pm 3.63$ & $0.000^{\mathrm{a}}$ \\
(mg) & & & & \\
Serat $(\mathrm{g})$ & & & & \\
\hline
\end{tabular}

a Uji beda ANOVA

b Uji beda Kruskal-Wallis 
Perbedaan asupan serat selama intervensi pada kelompok perlakuan salah satunya disebabkan karena pengaruh pemberian nata de coco. Pemberian nata de coco pada kelompok 1 dan 2 dengan kandungan serat berturut-turut $4.8 \mathrm{~g}$ dan $9.6 \mathrm{~g}$ yang berkontribusi menambah asupan serat per hari bagi subjek intervensi.
Pengaruh konsumsi nata de coco terhadap kadar kolesterol LDL dan HDL

Intervansi yang diberikan dalam penelitian ini adalah nata de coco dengan kandungan serat 4,9 g dan 9,6 g/hari pada kelompok 1 dan 2 selama 14 hari.

Tabel 5. Pengaruh pemberian nata de coco terhadap kadar kolesterol LDL antar kelompok sebelum dan sesudah intervensi

\begin{tabular}{cccccc}
\hline Kelompok & $\begin{array}{c}\text { Sebelum } \\
(\mathbf{m g} / \mathbf{d l})\end{array}$ & $\begin{array}{c}\text { Sesudah } \\
(\mathbf{m g} / \mathbf{d l})\end{array}$ & $\begin{array}{c}\Delta \\
(\mathbf{m g} / \mathbf{d l})\end{array}$ & $\begin{array}{c}\Delta \\
\mathbf{\%}\end{array}$ & P \\
\hline Kontrol & $151.29 \pm 23.31$ & $155.01 \pm 23.34$ & $-3.73 \pm 4.85$ & 2.54 & $0.005^{*}$ \\
Perlakuan 1 & $147.91 \pm 34.86$ & $138.71 \pm 28.13$ & $9.20 \pm 21.76$ & 4.47 & $0.091^{*}$ \\
Perlakuan 2 & $147.56 \pm 31.10$ & $138.25 \pm 33.38$ & $9.31 \pm 16.92$ & 6.25 & $0.044^{*}$ \\
\hline
\end{tabular}

* Uji beda paired-samples t test

Tabel 5 menunjukkan adanya penurunan rata-rata kolesterol LDL pada kelompok perlakuan, tetapi secara statistik penurunan yang bermakna hanya terjadi pada kelompok perlakuan $2(\mathrm{p}<0.05)$. Penurunan kolesterol LDL pada kelompok perlakuan 1 sebesar 4.5\%, pada kelompok perlakuan 2 sebesar $6.3 \%$. sementara pada kelompok kontrol terjadi peningkatan kolesterol LDL sebesar 2.5\% secara statistik bermakna $(\mathrm{p}<0.05)$.

Tabel 6. Pengaruh pemberian nata de coco terhadap kadar kolesterol HDL antar kelompok sebelum dan sesudah intervensi

\begin{tabular}{cccccc}
\hline Kelompok & $\begin{array}{c}\text { Sebelum } \\
(\mathbf{m g} / \mathbf{d l})\end{array}$ & $\begin{array}{c}\text { Sesudah } \\
(\mathbf{m g} / \mathbf{d l})\end{array}$ & $\begin{array}{c}\Delta \\
(\mathbf{m g} / \mathbf{d l})\end{array}$ & $\begin{array}{c}\Delta \\
\text { \% }\end{array}$ & P \\
\hline Kontrol & $47.63 \pm 3.50$ & $47.33 \pm 3.56$ & $0.30 \pm 1.79$ & 0.56 & $0.570^{\mathrm{b}}$ \\
Perlakuan 1 & $45.56 \pm 3.11$ & $51.17 \pm 7.55$ & $-5.61 \pm 6.06$ & 12.14 & $0.001^{\mathrm{a}}$ \\
Perlakuan 2 & $44.00 \pm 7.17$ & $45.38 \pm 8.53$ & $-1.38 \pm 5.63$ & 3.59 & $0.361^{\mathrm{b}}$ \\
\hline
\end{tabular}

a Uji beda paired-samples t test

b Uji beda Wilcoxon

Tabel 6 menunjukkan bahwa pada kelompok perlakuan 1 terdapat peningkatan kadar kolesterol HDL secara signifikan sebelum dan sesudah intervensi $1 \quad(\mathrm{p}<0.05)$, sedangkan kadar kolesterol HDL pada kelompok kontrol dan perlakuan 2 berturut-turut terjadi penurunan dan peningkatan sebesar $0.5 \%$ dan $3.6 \%$ namun secara statistik tidak bermakna.

\section{Pengaruh konsumsi nata de coco terhadap rerata perubahan kolesterol LDL dan HDL}

Perbedaan rerata perubahan kolesterol LDL dan HDL antar ketiga kelompok dianalisis dengan uji Kruskal-Wallis, perbedaan rerata perubahan kolesterol LDL dan HDL antara kelompok perlakuan 1 dan 2 dianalisis dengan uji independent-samples t test.

Tabel 7. Perbedaan rerata perubahan kolesterol LDL dan HDL antar ketiga kelompok

\begin{tabular}{ccccc}
\hline$\Delta$ (mg/dl) & Kontrol & Perlakuan 1 & Perlakuan 2 & P \\
\hline$\Delta$ Kol. LDL & $-3.73 \pm 4.85$ & $9.20 \pm 21.76$ & $9.31 \pm 16.92$ & $0.012^{\mathrm{b}}$ \\
$\Delta$ Kol. HDL & $0.30 \pm 1.79$ & $-5.61 \pm 6.06$ & $-1.38 \pm 5.63$ & $0.002^{\mathrm{a}}$ \\
\hline
\end{tabular}

a Uji beda ANOVA

b Uji beda menggunakan Uji Kruskal-Wallis

Tabel 7 menunjukkan terdapat perbedaan perubahan kadar kolesterol LDL dan HDL yang bermakna $(\mathrm{p}<0.05)$ antara ketiga kelompok.
Sementara uji beda antar kelompok perlakuan 1 dan 2 tidak terdapat perbedaan perubahan kadar kolesterol LDL ( $\mathrm{p}=0.863)$, namun secara deskriptif 
penurunan kolesterol LDL tertinggi terdapat pada kelompok perlakuan 2. Sementara uji beda antar kelompok perlakuan terdapat perbedaa perubahan kadar kolesterol HDL yang bermakna ( $\mathrm{p}=0.043)$, seperti yang terlihat pada tabel 8. Secara keseluruhan dapat disimpulkan bahwa pemberian nata de coco baik dosis $160 \mathrm{~g}$ maupun $320 \mathrm{~g}$ per hari selama dua minggu memberikan pengaruh yang sama terhadap penurunan kolesterol LDL subyek sementara terdapat pengaruh yang berbeda dalam peningkatan kolesterol HDL.

Tabel 8. Perbedaan rerata perubahan kolesterol LDL dan HDL antar kelompok perlakuan

\begin{tabular}{cccc}
\hline$\Delta(\mathbf{m g} / \mathbf{d l})$ & Perlakuan 1 & Perlakuan 2 & P \\
\hline$\Delta$ Kol. LDL & $9.20 \pm 21.76$ & $9.31 \pm 16.92$ & $0.863^{\mathrm{b}}$ \\
$\Delta$ Kol. HDL & $-5.61 \pm 6.06$ & $-1.38 \pm 5.63$ & $0.043^{\mathrm{a}}$ \\
\hline
\end{tabular}

a Uji beda independent-samples $t$ test

b Uji beda Mann-Whitney test

\section{PEMBAHASAN}

Subjek dalam penelitian ini adalah wanita, dislipidemia dan belum mengalami menopause. Penelitian di Brazil menunjukkan bahwah 85.3\% responden wanita usia diatas 20 tahun mengalami dislipidemia. ${ }^{9}$ Risiko dislipidemia meningkat pada wanita yang mengalami menopause, hal ini terjadi karena berkurangnya hormon estrogen dalam tubuh. Hormon estrogen dapat mencegah terjadinya atherosclerosis dengan menaikkan kadar HDL dan menurunkan kadar LDL. Selama masa pre-menopause estrogen melindungi wanita dari penyakit dislipidemia. ${ }^{1,10}$

Sebaran umur terbesar 40-49 tahun (53.8\%). Risiko dislipidemia meningkat berbanding lurus dengan peningkatan umur seseorang. Hal ini diakibatkan karena makin berkurangnya kemampuan atau aktivitas reseptor LDL, hal ini dapat menurunkan laju katabolik LDL sehingga menyebabkan LDL darah meningkat dan berisiko terjadinya atherosclerosis. ${ }^{1,10,11}$

Hasil uji beda menunjukkan adanya perbedaan status gizi antar ketiga kelompok. Sebagian besar $(51.9 \%)$ subjek penelitian tergolong obesitas. Peningkatan IMT berbanding lurus dengan peningkatan risiko penyakit jantung. Jaringan adipose yang berlebihan sangat mempengaruhi terjadinya penyakit jantung melalui berbagai faktor risiko, salah satunya faktor dislipidemia. ${ }^{1,10,12}$ VLDL merupakan lipoprotein dengan kandungan trigliserid tertinggi yaitu mencapai 50\%, banyaknya jaringan adipose pada penderita obesitas menyediakan banyak trigliserid untuk membantu sintesis VLDL. Dalam sisrkulasi, trigliserid di VLDL akan mengalami hidrolisis oleh enzim lipoprotein lipase (LPL), dan VLDL berubah menjadi IDL yang juga mengalami hidrolisis trigliserid dan berubah menjadi LDL yang tinggi kolesterol. ${ }^{1,10,16}$
Hasil recall asupan energi, kerbohidrat, protein, lemak, kolesterol dan serat sebelum intervensi tidak terdapat perbedaan yang bermakna antar ketiga kelompok, sementara asupan selama intervensi pada ketiga kelompok juga tidak terdapat perbedaan yang bermakana, kecuali asupan kolesterol dan serat. Rata-rata asupan kolesterol sebelum intervensi pada kelompok kontrol, perlakuan 1 dan perlakuan 2 berturut-turut sebesar $178.61 \mathrm{mg}, 153.54 \mathrm{mg}$ dan $133.23 \mathrm{mg}$. Setelah intervensi terjadi penurunan asupan kolesterol pada kelompok kontrol dan perlakuan 1 menjadi $163.85 \mathrm{mg}$ dan $98.41 \mathrm{mg}$. Sedangkan pada kelompok perlakuan 2 terjadi peningkatan rata-rata asupan kolesterol menjadi $143.77 \mathrm{mg}$. Peningkatan rata-rata asupan kolesterol ini terjadi karena asupan makanan tinggi kolesterol seperti telur, daging, dan makanan olahan yang mengandung klesterol. Asupan kolesterol dan lemak tak jenuh dapat meningkatkan kadar kolesterol LDL dengan bersama-sama menurunkan aktivitas reseptor LDL. ${ }^{1,14}$

Asupan serat sebelum intervensi, rata-rata 8.9 g per hari. Jumlah ini masih dibawah hasil riset Puslitbang Gizi Depkes RI Tahun 2001, dimana rata-rata konsumsi serat penduduk Indonesia adalah 10.5 gram per hari. Angka ini menunjukkan bahwa penduduk Indonesia baru memenuhi kebutuhan seratnya sekitar $1 / 3$ dari kebutuhan ideal 20-25 gram setiap harinya. ${ }^{13}$ Selama intervensi rata-rata asupan serat mengalami peningkatan menjadi $13.6 \mathrm{~g}$ per hari pada kelompok perlakuan 1 dan $16.8 \mathrm{~g}$ per hari pada kelompok perlakuan 2 . Peningkatan rata-rata asupan serat ini terjadi karena kontribusi asupan serat dari nata de coco.

Rata-rata asupan lemak selama intervensi untuk kelompok perlakuan 2 (49.96 g) atau 28.3\% dari total energi, lebih tinggi dari pada kelompok perlakuan $1(47.89 \mathrm{~g})$ atau $23.5 \%$ dari total energi. 
Sementara American Heart Association (AHA) 2006 merekomendasikan asupan lemak 20-25\% dari total energi, yang terdiri dari lemak tak jenuh tunggal sampai $10 \%$, lemak tak jenuh ganda sampai $10 \%$, lemak jenuh dibawah $7 \%$ dan lemak trans dibawah $1 \%$ untuk mengurangi faktor risiko penyakit jantung. Salah satunya mengurangi terjadinya dislipidemia. ${ }^{1}$ Asupan lemak pada kelompok perlakuan 2 melebihi batas rekomendasi diet AHA. Mekanisme asam lemak tak jenuh ganda dapat menurunkan kolesterol masih belum sepenuhnya dipahami. Namun, sudah jelas bahwa salah satu mekanisme yang terlibat adalah peningkatan aktivitas reseptor LDL oleh asam lemak tak jenuh ganda dan tak jenuh tunggal, sehingga terjadi peningkatan laju katabolik LDL. Sedangkan asam lemak jenuh menyebabkan terbentuknya partikel VLDL berukuran lebih kecil yang mengandung kolesterol relatif lebih banyak. $^{1,14}$ sementara kondisi tinggi kolesterol LDL dapat mempengaruhi kadar kolesterol HDL.

Kadar kolesterol LDL dan HDL sebelum intervensi pada ketiga kelompok tidak terdapat perbedaan yang bermakna. Pemberian nata de coco sebanyak $160 \mathrm{~g}$ per hari dan $320 \mathrm{~g}$ per hari berturut-turut menurunkan kadar kolesterol LDL sebanyak $4.5 \%$ dan $6.3 \%$. Secara statistik penurunan kolesterol LDL yang bermaknan terjadi pada kelompok perlakuan 2 dengan penurunan $6.3 \%$ atau sebesar $9.31 \mathrm{mg} / \mathrm{dl}$. Sedangkan kelompok kontrol mengalami kenaikan kolesterol LDL sekitar $2.5 \%$ atau sebesar $3.73 \mathrm{mg} / \mathrm{dl}$ dan secara statistik bermakna.

Penurunan kadar kolesterol LDL dipengaruhi oleh kandungan serat pangan yang terkandung di dalam nata de coco. Sebanyak $160 \mathrm{~g}$ dan $320 \mathrm{~g}$ nata de coco yang digunakan sebagai variabel bebas dalam penelitian ini mengandung $4.8 \mathrm{~g}$ dan $9.6 \mathrm{~g}$ serat pangan. Penelitian di Thailand dengan pemberian suplemen serat serealia yang dikombinasikan dengan $40 \%$ serat nata de coco pada pasien hiperlipidemia dengan total kandungan serat pangan $2.7 \mathrm{~g}$ per hari, selama 20 minggu dapat menurunkan kadar kolesterol LDL sebesar $2.3 \%(3.9 \mathrm{mg} / \mathrm{dl})$ meskipun tidak bermakna. ${ }^{7}$

Secara statistik terjadi peningkatan kadar kolesterol HDL yang bermakna setelah pemberian nata de coco pada kelompok perlakuan 1 dengan peningkatan sebesar 12,1\%. Pada kelompok perlakuan 2 juga terjadi peningkatan kolesterol HDL sebesar 3,6\% namun secara statistik tidak bermakna. Hal ini diduga karena kelompok perlakuan 2 mengalami peningkatan asupan kolesterol dan lemak melebihi batas rekomendari
AHA selama intervensi. Sedangkan pada kelompok kontrol terjadi penurunan kolesterol HDL sebersar $0.5 \%$ secara statistik tidak bermakna.

Terjadinya peningkatan kolesterol HDL mungkin disebabkan oleh adanya kenaikan apolipoprotein A dengan mekanisme yang belum diketahui dengan jelas. Apolipoprotein A merupakan salah satu protein pendukung terbentuknya partikel HDL ${ }^{1,15,16}$ Sebuah penelitian pada tikus Sprague Dawley hiperkolesterolemi, dengan pemberian nata de coco kering yang mengandungan serat $0,18 \mathrm{~g} ; 0,36 \mathrm{~g} ; 0,54 \mathrm{~g}$ dan $0,72 \mathrm{~g}$ per hari selama 2 minggu, diperoleh hasil peningkatan HDL yang bermakna, dengan peningkatan kadar kolesterol HDL berturut-turut $4,97 \% ; 35,73 \% ; 46,86 \%$; dan $66,05 \% .^{8}$ Sementara penelitian di Thailand dengan pemberian serat pangan $2,7 \mathrm{~g} /$ hari, selama 20 minggu terdapat peningkatan kadar kolesterol HDL sebesar 7,7\% $(3,9 \mathrm{mg} / \mathrm{dl})$ secara statistik peningkatan ini tidak bermakna. $^{\text {? }}$

Jenis serat dalam nata de coco antara lain selulosa, hemiselulosa dan lignin. ${ }^{8}$ Serat tersebut mampu mengikat garam empedu di dalam lumen usus sehingga tidak dapat direabsorpsi kembali melalui jalur metabolisme eksogen dan akan diekskresikan bersama feses. Akibatnya terjadi peningkatan ekskresi kolesterol bersama feses dan penurunan jumlah kolesterol yang menuju ke hati. Penurunan jumlah kolesterol di hati akan meningkatkan pengambilan kolesterol dari darah untuk disintesis kembali menjadi garam empedu yang baru. ${ }^{1,16}$ Hal ini lah yang dapat menurunkan kadar kolesterol yang beredar dalam darah. Selain itu hasil fermentasi serat tidak larut di usus besar dapat menghasilkan asam lemak rantai pendek, dimana asam lemak rantai pendek berperan dalam menghambat sisntesis HMG-KoA reduktase sehingga sintesis kolesterol di hati juga menurun. ${ }^{5}$ Kolesterol LDL merupakan lipoprotein dengan kandungan kolesterol tertinggi yaitu mencapai $45 \%,{ }^{15}$ dengan terhambatnya sisntesis kolesterol oleh serat dari nata de coco secara tidak langsung akan menghambat sintesis LDL oleh hati.

\section{KESIMPULAN}

Pemberian nata de coco dengan dosis $160 \mathrm{~g}$ dan $320 \mathrm{~g}$ per hari selama 14 hari dapat menurunan kadar kolesterol LDL dan meningkatkan kadar klesterol HDL pada wanita dengan dislipidemia. Penurunan kolesterol LDL sebesar $9.31 \mathrm{mg} / \mathrm{dl}$ $(6,3 \%)$ terjadi pada kelompok yang menerima dosis $320 \mathrm{~g}$ dan hasil tersebut bermakna secara 
statistik $(\mathrm{p}<0,05)$. Sementara pada dosis $160 \mathrm{~g}$ nata de coco per hari mampu meningkatkan kolesterol HDL sebesar $5.61 \mathrm{mg} / \mathrm{dl}(12,1 \%)$ dan secara statistik bermakna $(\mathrm{p}<0,05)$.

\section{DAFTAR PUSTAKA}

1. Krummel DA. Medical Nutrition Therapy for Cardiovascular Disease. In : L. Kathleen Mahan, Sylvia Escott-Stump, editors. Krause's Food and Nutrition Therapy. $12^{\text {th }}$ edition. Philadelphia, USA - Saunders Elsevier; 2008.p.833;61

2. Depkes RI. Laporan Hasil Riset Kesehatan Dasar (RISKESDAS) Nasional 2007. Jakarta : Depkes RI, 2008.

3. Dinas Kesehatan Kota Semarang. Laporan Kematian Akibat Penyakit Tidak Menular. 2012.

4. Brunzell, John D. Hypertriglyceridemia. N Engl J Med 2007;357:1009-17.

5. Mayes PA. Sintesis, Pengangkutan, dan Ekskresi Kolesterol. Dalam: Murray RK, Granner DK, Mayes PA, Rodwell VW, editor. Biokimia harper $27^{\text {th }}$ ed. Jakarta: EGC; 2006.

6. Kritchevsky D, Bonfield C, Anderson JW. Dietary Fiber; Chemistry, Physiology, and Health Effects. New York: Plenum Press; 1990.

7. Mesomya W, Pakpeankitvatana V, Komindr S, Leelahakul P, Cuptapun Y, Hengsawadi D, et al. Effects of health food from cereal and nata de coco on serum lipids in human. Songklanakarin J. Sci. Technol 2006, 28(Suppl. 1):23-28.

8. Setyaji YD. Pengaruh pemberian nata de coco terhadap kadar kolesterol LDL dan HDL pada tikus hiperkolesterolemia. Artikel penelitian
Program Studi Ilmu Gizi Fakultas Kedokteran UNDIP Semarang. 2011

9. Luiz JS et al. Prevalence of dyslipidemia and risk factors in Campos dos Goytacazes, in the Brazilian State of Rio de Janeiro. Arquivos Brasileiros de Cardiologia. 2003; vol.81:No.3.

10. Soeharto I. Serangan Jantung dan Stroke. Jakarta : PT Gramedia Pustaka Utama, 2003.

11. Le D, Garcia A, Lohsoonthorn V, Williams MA. Prevalence and risk factors of hypercholesterolemia among Thai men and women receiving health examinations. Southeast Asian J Trop Med Public Health. 2006; Vol 37:No.5.

12. Dixon JB, O'Brien P. A disparity between conventional lipid and insulin resistance markers at body mass index levels greater than $34 \mathrm{~kg} / \mathrm{m}(2)$. Int J Obes Relat Metab Disord.2001;25:793-7.

13. Andrea A. Aspek medis Penyakit Jantung dan Pembuluh Darah. Dalam : Pertemuan Ilmiah Nasional ke-3 : 2007 Juli 19-21; Semarang. Asosiasi Dietisien Indonesia DPD JAwa Tengah; 2007.

14. Lamarche B, Lemieux I, Despre's JP. The small, dense LDL phenotype and the risk of coronary heart disease: epidemiology, patho-physiology and therapeutic aspects. DiabetesMetab. 1999;25:199211.

15. Stryer L. Cholesterol Metabolism and Blood Lipoprotein by Biochemistry $4^{\text {th }}$ ed. Stanford University: $\quad \mathrm{WH}$ Freedman and company; 1995:525-44.

16. Adam John MF. Dislipidemia. Dalam : Sudoyo AW, Hasi BS, Alwi I, Simadibrata M, Setiati S, editor. Buku Ajar Ilmu Penyakit Dalam. Edisi 4. Jakarta : PP IPD FK UI; 2006.p.1926;7. 